DOI 10.31558/2307-2318.2020.4.24
УДК 338.2:004.9
JEL: F20, O14, O32, М21

Бей Г.В.

к.е.н., доцент кафедри менеджменту та поведінкової економіки Донецького національного університету імені Василя Стуса

ORCID: 0000-0002-6367-3494

h.larycheva@donnu.edu.ua

\title{
СТРАТЕГІЧНІ ТА ТАКТИЧНІ ПИТАННЯ УСПІШНӦ̈ ТРАНСФОРМАЦІЇ БІЗНЕСУ В УМОВАХ НОВОЇ ЦИФРОВОЇ РЕАЛЬНОСТІ
}

В статті розглянуто характерні особливості та ключові питання здійснення успішної трансформації бізнесу в умовах становлення цифрової економіки та появи новітніх викликів соціально-економічного розвитку. Доведено, що розвиток цифрової економіки пришвидшується у зв'язку із впливом всеохоплюючого поширення інформаційних, комунікаційних та проривних технологій, виникненням на їх основі комбінаторного ефекту, що дозволяє отримувати безліч нових технологічних та управлінських рішень. Визначено характер обгрунтованих змін, які супроводжують економічну діяльність суб'єктів ведення бізнесу в нових умовах, зокрема зміни у ринковій моделі економічної поведінки, технологічній інфраструктурі, бізнес-процесах, та ключові галузі, які зазнають найбільшого впливу під дією проривних цифрових технологій. Представлено типові тенденції здійснення цифрових трансформацій в різних галузях та проаналізовано чинники, що дозволяють досягати успішності в реалізації проєктів цифрових перетворень та ступінь розвиненості базової цифрової інфраструктури. Сформульовано основні положення реалізації успішних цифрових трансформацій бізнесу з точки зору стратегічного бачення та визначено першочергові тактичні питання досягнення бажаного рівня конкурентоспроможності і утримання лідерських позицій.

Ключові слова: цифрова економіка, трансформація бізнесу, проривні технології, стратегія, інформаційні системи.

Рис - 3, Табл. - 1, Літ. - 15

Постановка проблеми. Швидкоплинні зміни, що відбуваються сьогодні у загальносвітовому вимірі, характеризують формування нової світової реальності, що суттєво відрізняється від усталеної моделі економічних взаємовідносин. Для утримання конкурентних позицій і забезпечення стратегічних переваг у майбутньому компаніям вже не достатньо спиратись лише на традиційні бізнес-моделі, які зарекомендували себе як надійні джерела прибутковості, оскільки вони не дають достатньої гнучкості, повільно реалізуються і не здатні швидко реагувати на зміни. Успішні в недалекому минулому компанії, що виявились неспроможними пристосуватись до новітнього середовища, втрачають свої позиції або миттєво перетворюються на аутсайдерів галузі, і останні події, в тому числі економічні наслідки пандемії COVID-19, лише посилюють потребу у перегляді стратегічних і тактичних питань подальшого розвитку. Цифрові трансформації стають не просто перспективою на майбутнє, а перетворюються у життєву необхідність, що допомагає долати загрози і 
формувати нові перспективи за умови комплексного підходу і швидкого реагування. Одночасно 3 тим, успішна трансформація обмежується реальною готовністю інфраструктури, бізнес-процесів, персоналу та наявних продуктів і сервісів до переходу на новий рівень, відсутністю належного рівня координації та управлінського супроводження, досвіду, мережі бізнес агентів та агентів інновацій і агентів сприяння тощо. 3 огляду на це, формування стратегічного і тактичного бачення для здійснення трансформацій, викликаних новітніми умовами ведення бізнесу, виявлення проблемних питань і визначення конкретних дієвих кроків для впровадження успішних перетворень є особливо актуальними і потребують науково-обгрунтованого підходу.

Аналіз останніх досліджень і публікацій. Питанням впливу процесів цифровізації на розвиток суспільства та економіки приділяється значної уваги у працях теоретиків та практиків економічної науки, зокрема Д. Тапскота, Г. Боумана [1], O. Гриценко [2], К. Ковтонюк, М. Колота, Н. Краус, К. Краус та ін. Напрямки та дієві інструменти реалізації успішної трансформації бізнесу, нові бізнес-моделі та етапи стратегічних перетворень досліджували I. Даніелс, Д. Роджерс [3], А. Остервальдер, Дж. Віпін [4], М. Вестерлунд, А. Наторіна [5], Н. Лісова [6], Г. Ткачук. Не применшуючи суттєвого дослідницького внеску наведених вчених відзначимо в той же час необхідність перегляду існуючих стратегічних та тактичних орієнтирів ведення бізнесу в цифрову епоху, оскільки в умовах обмеженості ресурсів, довготривалих кризових явищ, глобальних викликів і змін, спричинених розвитком цифрових технологій, особливо значущою $€$ здатність бізнес-системи швидко і ефективно адаптуватись, ефективно вирішувати проблеми і долати бар'єри для зайняття лідерських позицій у обраній галузі економічної діяльності.

Виклад основного матеріалу. Поняття нової цифрової реальності визначається бурхливим розвитком інформаційних, комунікаційних та діджитал або цифрових технологій, пов'язаних із інтенсифікацією використання Інтернет та смарт-пристроїв, спроможних швидко передавати, обробляти, аналізувати і зберігати інформацію [7]. Як зазначають в своїй роботі Н. та К. Краус [8] для цифрової економіки характерна висока цінність інформації, що має бути невичерпною, точною, надійною, правдивою та своєчасною. При цьому зміщуються акценти ведення економічної діяльності, оскільки вона переходить у так званий «віртуальний» простір, та тепер стає менш важливим, якими іншими ресурсами володіє компанія, а от від того, якої якості інформацію і наскільки вчасно вона отримує 3 одночасною спроможністю обробити і прийняти правильне рішення, значним чином залежить загальний результат та ефективність. Окрім того змінюються шаблони поведінки при веденні бізнесу і споживанні, оскільки на перший план виходить задоволеність споживачів не лише якістю продукту, але й загальним рівнем та переліком доступних сервісів, спроможністю компанії пропонувати нову, відмінну від класичної, ціннісну пропозицію, здатність постійно підтримувати комунікації зі споживачем (клієнтом).

Отже, відбувається цифрова трансформація соціально-економічних відносин, що зачіпає усі сфери життєдіяльності за рахунок масового поширення і застосування новітніх цифрових технологій, полегшення їх доступності, удосконалення навичок використання (набуття цифрових навичок) серед учасників цих відносин, появи нових цифрових платформ взаємодії тощо. Слід відзначити, що особливістю процесів цифрової трансформації $\epsilon$ їх посилення за рахунок виникнення комбінаторного ефекту або ж ефекту взаємоприскореного розвитку завдяки можливості одночасного застосування значної кількості нових технологій [9]. Різні поєднання цих технологій (штучного інтелекту, роботизації, віртуальної та доповненої реальності, машинного 
навчання, інтернету речей, блокчейн тощо) дозволяють отримувати інші, більш ефективні рішення, які можна згрупувати у три напрямки: трансформація бізнесмоделей, моделей операційної діяльності та інновацій клієнтського досвіду (рис. 1).

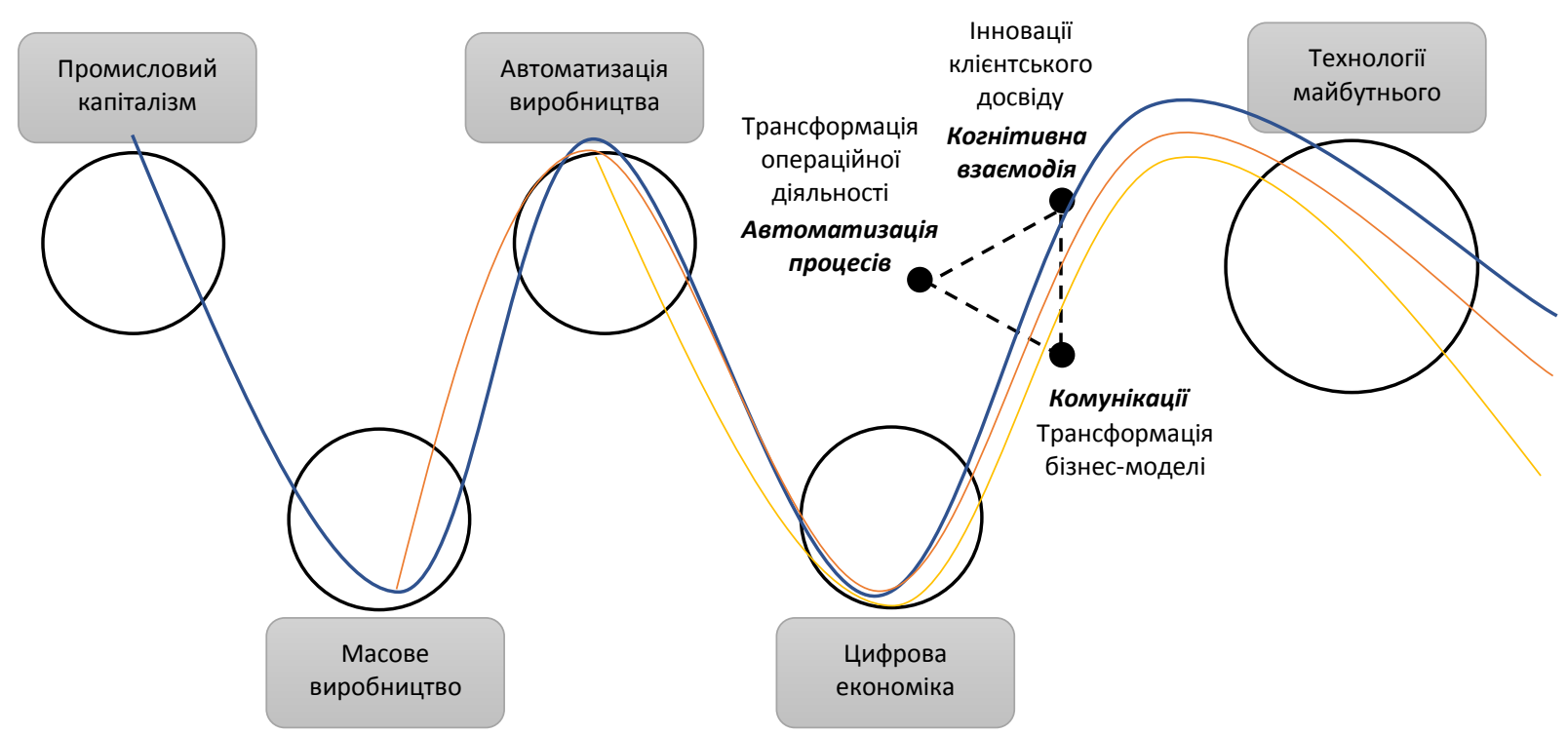

Рисунок 1. Виникнення комбінаторного ефекту новітніх технологій та його вплив на основі аспекти ведення бізнесу

Джерело: складено автором

Таким чином, поняття цифрової трансформації передбачає максимально повне використання високотехнологічних рішень та їх поєднання з метою автоматизації, спрощення та одночасного підвищення ефективності абсолютно всіх бізнес-процесів. Тобто, цифрова трансформація охоплює не лише проєкти з впровадження проривних технологій у процеси операційної і виробничої діяльності, такі як технології Смартфабрики (розумне виробництво, цифрова модернізація операційних та бізнес-процесів) та її логічного продовження у якості концепції Індустрії 4.0 (оновлення бізнес-процесів iз застосуванням новітніх кіберсистем) [10], але і повний перегляд існуючої моделі ведення бізнесу, ланцюжків створення цінності та способів і каналів взаємодії 3 клієнтами, постачальниками, іншими стейкхолдерами.

Управління будь-якою трансформацією бізнесу в межах певної організації передбачає здійснення ефективного менеджменту змін, тобто управління операційними, структурними, технологічними, культурними змінами та адаптацією персоналу до них. У випадку цифрових трансформацій досягти максимальних переваг від їх впровадження можливо завдяки реалізації:

1. Змін у ринковій та бізнес-моделі, ціннісній пропозиції, продуктах та послугах.

2. Змін в технологічній інфраструктурі.

3. Змін у здійсненні бізнес-процесів.

4. Змін в організаційній структурі, культурі та відповідальності персоналу.

Зрозуміло, що для різних сфер діяльності трансформаційні рішення будуть різними, оскільки цифрова реальність по-різному впливає на різні галузі. Згідно досліджень Інституту розвитку менеджменту у їх звіті під назвою Digital Vortex 2019 до галузей, діяльність яких знаходиться під найбільшим впливом цифрових змін у зв'язку зі швидкістю оновлення цифрових технологій та сервісів відносяться: медіа та розваги, 
технологічні продукти та послуги, телекомунікації, торгівля, фінансові сервіси, туризм. Найменш схильні до цифрових змін будівництво, енергетика, виробництво, медицина, товари народного вжитку (табл. 1).

Таблиця 1

Розподіл галузей за рівнем впливу проривних технологій

\begin{tabular}{|l|l|l|}
\hline & \multicolumn{1}{|c|}{2017 рік } & \multicolumn{1}{|c|}{2019 рік } \\
\hline & Медіа та розваги & Медіа та розваги \\
\hline & $\begin{array}{l}\text { Технологічні продукти та } \\
\text { сервіси }\end{array}$ & $\begin{array}{l}\text { Технологічні продукти та } \\
\text { сервіси }\end{array}$ \\
\hline & Торгівля & Телекомунікації \\
\hline & Фінансові сервіси & Фінансові сервіси \\
\hline & Телекомунікації & Туризм \\
\hline & Товари масового споживання & Транспорт та логістика \\
\hline & Псвіта & Освіта \\
\hline & Туризм & Професійні послуги послуги \\
\hline 0 & Виробництво & Тови масового споживання \\
\hline 1 & Транспорт та логістика & Медицина та фармацевтика \\
\hline
\end{tabular}

Джерело: складено автором за [11, с. 4]

У сфері медіа та розваг характерними є найвищі рівні перетворень завдяки розширенню каналів здійснення комунікацій зі споживачами інформаційних продуктів та послуг. Деякі галузі (такі як видавництво та друкарська справа, музична та кіноіндустрія тощо) трансформувались кардинально та змушені були повністю переглянути існуючі бізнес-моделі.

Високі технологічні рішення напряму залежать від інформаційно-комунікаційної підтримки і поширеності цифрових технологій, що дозволило галузевим гравцям досягти безпрецедентного розуміння ринку, імплементувати систему моніторингу та контролю, охопити нові сфери діяльності та ринкові ніші.

Телекомунікації змінюють формат надання продукту та бізнес-модель, орієнтуючись на вимоги споживачів, які прагнуть отримувати розширений доступ завдяки зміні основного каналу трансляції (з аналогового на цифровий).

Ритейл перетворюється на омніканальні структури, орієнтовані на взаємодію 3 клієнтами здебільшого через віртуальне середовище, отримують можливість швидко реагувати на потреби споживачів та прогнозувати їхню поведінку.

У сфері фінансових послуг проривні технології призвели до появи більш якісних та клієнтоорієнтованих продуктів та сервісів, удосконалення системи взаємодії 3 клієнтами та доступності фінансових послуг, модернізації процесів електронного банкінгу.

Зрозуміло, що під впливом пандемії COVID19 структура цього переліку зазнала суттєвих змін, посилюючи перебіг трансформацій у тих галузях, що знаходились на зовнішніх колах цифрової воронки.

Так, з об'єктивних причин активізувався ринок охорони здоров'я, використання цифрових технологій у якому дозволяє розширювати спектр можливостей надання медичних послуг, утворювати медичні мережі, досягати персоналізованого підходу до обслуговування. Сфера виробництва 3 огляду на необхідність терміново обмежити рівень присутності персоналу на робочих місцях змушена пришвидшувати 
синхронізацію бізнес-процесів та здійснювати перехід до застосування смарттехнологій виробництва і операційної діяльності з метою максимально задовільнити потреби споживачів та одночасно знизити витрати, а компанії з надання транспортних послуг зосередились на впровадженні технологій оптимізації логістичних переміщень у режимі реального часу, і отже отримали додаткові гарантії їх результативної діяльності.

Бізнес-структури, що не були готові до подібного типу загроз, опинились за межами конкурентної боротьби або змушені були терміново приймати рішення про зміну стратегічної поведінки і не завжди ці рішення були достатньо комплексними, щоб стати успішними. В першу чергу, це викликано неготовністю традиційних секторів до сприйняття нової реальності (нерозуміння можливостей та відсутність належного обгрунтування для здійсненні перетворень), їх бачення майбутнього 3 точки зору однобокого підходу до цифрових трансформацій (зосередженість на вдосконаленні операційної діяльності), відсутність цифрового лідерства (навичок прогнозувати та передбачати вірогідні майбутні тенденції, прозорого та відкритого процесу прийняття рішень, здатності швидко адаптуватись і вчитись новому).

Характерною особливістю дії проривних цифрових технологій $€$ їх здатність змінювати внутрішню структуру галузей економіки та дію п’яти їі сил за Портером, оскільки:

- зростає вартість конкуренції серед існуючих конкурентів, оскільки збільшується ємність ринку через зростання кількості нових гравців, що легше долають ринкові бар'єри;

- послаблюються або зникають взагалі перешкоди для входу в галузь;

- збільшується ризик заміщення продукції через виникнення нових товарів та послуг-субститутів;

- зростає торгова силу постачальників на основі переваг, які надає використання системи онлайн-закупівель та інформаційних систем управління;

- змінюється купівельна сила покупців у зв'язку із наявністю глобального доступу до цін та інформації про продукти, збільшення їхніх вимог та очікувань.

У звичних, передбачуваних умовах ведення бізнесу здійснення поступового пристосування до викликів цифрового середовища є обгрунтованим, та реалізується на основі першочергового перегляду ціннісної пропозиції, як це було успішно реалізовано у класичних кейсах таких компаній як Apple, Google, Facebook, Amazon тощо (рис.2).

\begin{tabular}{|c|c|c|c|c|}
\hline & Apple & Google & Facebook & Amazon \\
\hline $\begin{array}{c}\text { Традиційна } \\
\text { модель }\end{array}$ & $\begin{array}{l}\text { Унікальні } \\
\text { продукти }\end{array}$ & $\begin{array}{c}\text { Пристрої } \\
\text { широкого } \\
\text { вжитку }\end{array}$ & $\begin{array}{c}\text { Новини та } \\
\text { соціальний } \\
\text { досвід }\end{array}$ & $\begin{array}{c}\text { Пошук та } \\
\text { купівля } \\
\text { товарів }\end{array}$ \\
\hline $\begin{array}{c}\text { Цифрова } \\
\text { модель }\end{array}$ & $\begin{array}{c}\text { 1,5 млн } \\
\text { цифрових } \\
\text { застосунків }\end{array}$ & $\begin{array}{c}\text { 1,5 млн } \\
\text { цифрових } \\
\text { застосунків }\end{array}$ & $\begin{array}{c}\text { Платформа } \\
\text { для } \\
\text { сторонніх } \\
\text { мобільних } \\
\text { застосунків }\end{array}$ & $\begin{array}{c}\text { Послуги з } \\
\text { «контролю } \\
\text { особистого } \\
\text { життя» }\end{array}$ \\
\hline
\end{tabular}

Рисунок 2. Приклади трансформації ціннісної пропозиції в бізнес-моделях Apple, Google, Facebook, Amazon

Джерело: складено автором 
Дорожня карта створення нової ціннісної пропозиції у такому випадку містить наступні елементи: ідентифікація ключових споживачів за типами отримання цінності, визначення поточної цінності для кожного споживача (елементи цінності та загальна ціннісна пропозиція), визначення супроводжуючих загроз (нові технології, потреба у впровадженні змін, конкуренція та товари-субститути), оцінювання сильних сторін поточних складових пропонованої цінності, створення потенційно ціннісних елементів (нові технології, соціо-культурні та ділові тренди, незадоволені потреби). Відповідно до цієї дорожньої карти повинна бути сформована стратегія цифрової трансформації, оновлення операційних процесів та рішень автоматизації, прояснене бачення власної цифрової присутності (в тому числі на мобільних платформах), напрямків маркетингу, взаємодії з клієнтами, постачальниками, зовнішнім середовищем, безпекові питання тощо.

Незважаючи на зрозумілість наведених кроків лише близько $30 \%$ проєктів цифрових трансформацій можна назвати успішними, а зростання продуктивності та інші позитивні ефекти від проведених трансформацій відзначають не більше $16 \%$ власників бізнесу [12].

Об'єктивними причинами, що призводять до подібних низьких результатів на етапі реалізації цифрових перетворень, $є$ недостатня увага до людської (наявність спротиву співробітників, відсутність належної інформаційної та ресурсної підтримки 3 боку керівництва, недостатня зрозумілість цілей і очікуваного результату, слабкі чи недостатні комунікації) і технологічної (відсутність розуміння обсягів та детального плану трансформацій, відсутність або нестача бюджету і ресурсів на ії виконання, неточні чи надто складні метрики вимірювання іiї перебігу) складової.

Новітні умови цифрового середовища розглядаються більшістю власників бізнесу у якості загроз, а не можливостей, оскільки викликають розуміння невизначеності найближчого майбутнього, ризик повної втрати ринку або його частки, зниження прибутків, суттєвий відтік клієнтів, формування негативного іміджу тощо. 3 іншого боку, на українському ринку вже $є$ достатньо успішних кейсів фундаментальних цифрових трансформацій, що реалізовані до 2020 року.

Наприклад, агрохолдинг Kernel завершив реалізацію проєкту DigitalAgriBusiness (підвищення внутрішньої ефективності агробізнесу) та OpenAgriBusiness (створення зовнішньої екосистеми партнерів-агровиробників) на основі розробки спеціалізованої інформаційної системи для максимально точного управління виробничими процесами (прозорий процес закупівель і постачання, управління і моніторинг операцій у полях, метеомоніторинг, логістичні процеси).

Створення платформи єдиної комунікації в ПАТ «Укрнафта» розв’язало проблему інформування, навчання та підтримки персоналу в рамках реалізації різних проєктів, в тому числі впровадження системи ERP (планування ресурсів підприємства) із застосуванням хмарних технологій.

Один із найбільших українських банків Raiffeisen Bank Aval тривалий час здійснює цифрові трансформації, впроваджує нові сервісні моделі, автоматизує процеси одночасно із перетворенням традиційних банківських продуктів в електронні. У 2019 році банком звершено першу стадію реалізації проєкту Robotics Office, завдяки якому роботизовано 16 процесів, ще 8 заплановано до реалізації у 2020 році [13].

В наведених прикладах простежується тенденція до здійснення цифрових змін на основі адаптації світового досвіду оптимізації бізнес-процесів із використанням спеціалізованого програмного забезпечення та інформаційних систем управління, готових рішень хмарних технологій, розбудови корпоративних мереж. Найбільш 
докорінна і глибока цифрова трансформація сьогодні реалізується групою компаній DTEK у програмі Modus, де передбачено три хвилі цифровізації 3 пріоритетом підвищення операційної ефективності, безпеки виробництва, гнучкості і керованості бізнесу, розуміння ринку і зв'язків з клієнтами із досягненням у 2025 році повсюдного застосування цифрових технологій. У 2018-2019 році тут успішно впроваджено проєкти цифрової шахти, TEC, логістики, мереж та HR, а також цифрового родовища, офісу, закупівель і аналітики, на 2020 заплановано цифровізацію клієнтів та відновлюваних джерел енергії [14]. Тобто власники українських підприємств поступово приходять до розуміння важливості цифрових трансформацій та вже сформовано лідерів галузей, що готові ділитись досвідом та підтверджувати результативність правильного підходу.

3 огляду на останні події, світова економіка зазнає сьогодні масштабного впливу, що виражається не тільки у можливій рецесії, але у докорінній зміні поведінкових паттернів здійснення бізнесу та ведення побуту: до віртуального способу ведення економічних відносин долучаються ті категорії населення, які практично не користувались ним або не планували таку можливість у найближчій перспективі, віддалене виконання роботи, надання послуг та їх споживання демонструють неочікуваний рівень ефективності, цифрові рішення для бізнесу та алгоритми їх імплементації стають доступними та простими у використанні.

Все це стає можливим завдяки посиленню рівня наявності та доступності базової цифрової інфраструктури - за 10 років кількість домогосподарств із доступом в Інтернет та користувачів мобільної мережі на кожні 100 мешканців в Україні перевищила середні світові показники та майже досягла середнього рівня по Свропі

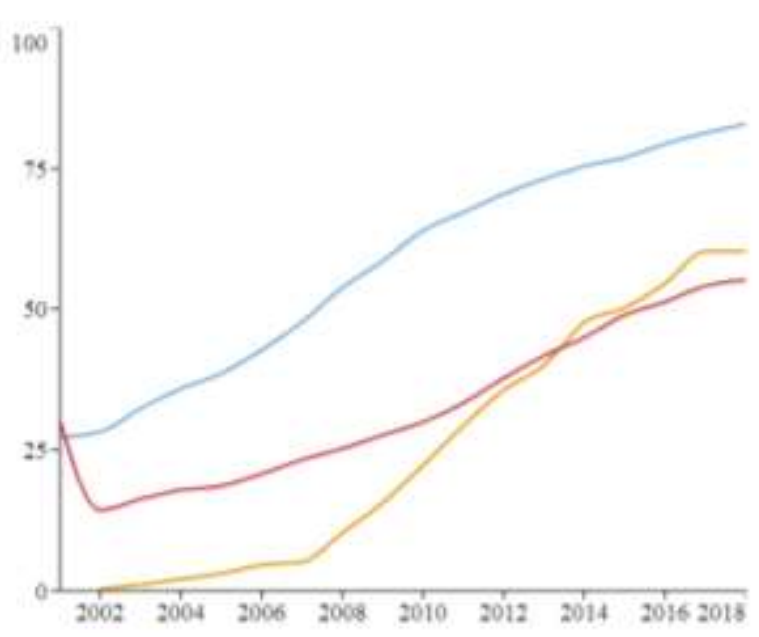

а) Кількість домогосподарств із доступом в Інтернет

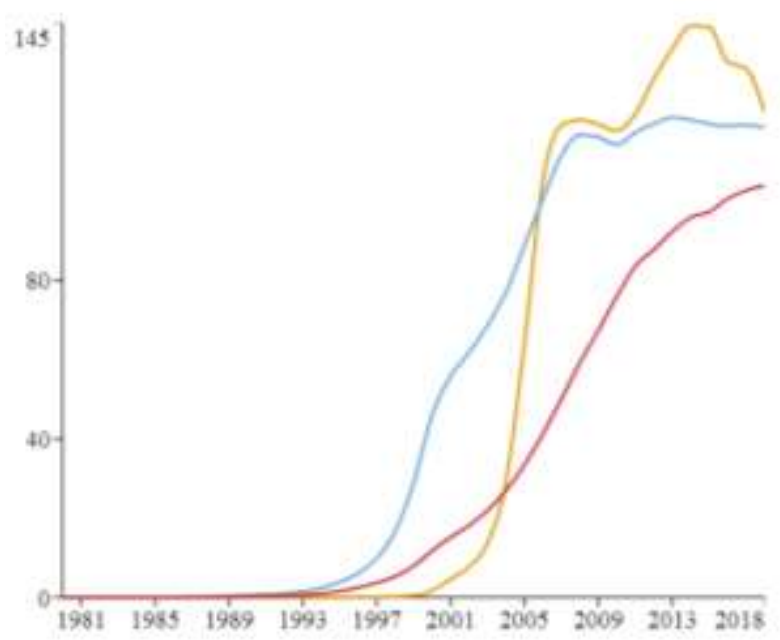

б) Кількість користувачів мобільної мережі

(рис.1).

Рисунок 3. Динаміка розвитку базової цифрової інфраструктури в Україні, Європі та світі, \%

Джерело: [15]

Щодня кількість нових користувачів цифрових послуг зростає, так само як i кількість віддалених взаємодій з будь-яких робочих питань, тому звичні стратегічні питання ведення бізнесу, такі як впевнений розвиток та генерація прибутку, розширюються запитами на збереження продуктивності працівників і трансформації бізнес-процесів, продуктів та сервісів, здійснення продажів. 
Необхідність цифрової трансформації, що більшістю власників бізнесу розглядалась у якості стратегічних перспектив, сьогодні перетворюється на тактичне питання, вимагає швидкої імплементації та пошуку простих рішень, які не потребують значних витрат. В той же час, без глибинної трансформації бізнес-процесів та перегляду існуючої бізнес-моделі здійснення цифрових трансформацій навряд чи призведе до довготривалої оптимізації, підвищення продуктивності і покращення досвіду взаємодії з основними стейкхолдерами. Довготривалий ефект досягається тоді, коли цілі цифрової трансформації чіткі та зрозумілі, а основні бізнес-процеси переглянуті відповідно до вимог діджиталізації.

Окрім того перед здійсненням цифрових трансформацій має бути виконана перевірка готовності технологічної інфраструктури і засобів кібербезпеки, бізнеспроцесів, персоналу, продуктів та сервісів, системи продажів.

Питання максимальної інтеграції усіх ключових сервісів для забезпечення тісної колаборації усіх зацікавлених сторін мають бути вирішені в першу чергу. Швидкий обмін даними забезпечується на основі сучасних i-net каналів, хмарні рішення оптимізують витрати на інфраструктуру та дозволяють здійснити оцифрування діяльності, чіткі і зрозуміли метрики - управляти реальною ефективністю. Всеохоплююча інтеграція веде до скорочення ланцюжка прийняття рішень, дозволяє автоматизувати рутинні процеси, пришвидшити документообіг, скоротити витрати на непродуктивні комунікації, оптимізувати роботу з масивами даних.

Дієва формула впровадження змін складається із п’яти елементів: формулювання бачення, розвиток навичок, формування мотивації, залучення ресурсів та розробки чіткого плану дій. Якщо якийсь елемент відсутній, процеси цифрових трансформацій перетворюються на хаос, уповільнюються, піддаються фрустрації або ведуть до марних витрат і значних помилок, що значним чином спонукає відмовитись від впровадження будь-яких змін і працювати у звичному режимі. Готовність до змін може бути оцінена на основі моніторингу розуміння персоналом, клієнтами, постачальниками, суспільством переваг, що вони надають, наявності фахівців необхідного рівня, спроможних реалізувати заплановані зміни, прозорості та доступності інформації щодо планів та етапів реалізації проєкту, можливостей покращити знання і навички в системі розвитку персоналу, зрозумілості та чіткості критеріїв вимірювання показників результативності, достатнього розвитку технологічної та цифрової інфраструктури, рішучості у наданні необхідних ресурсів. Результати цього моніторингу визначатимуть ключові питання, на яких мають зосередитись бізнес-структури 3 метою набуття конкурентних переваг в новітніх соціально-економічних умовах.

Висновки і перспективи подальших досліджень. 3 огляду на швидкоплинність та непередбачуваність розвитку взаємовідносин в умовах всеохоплюючої цифровізації економічних та соціальних процесів стратегічні питання забезпечення теперішньої і майбутньої стійкості представників різних галузей ведення бізнесу визначаються їхньою готовністю до здійснення комплексних і послідовних цифрових трансформацій. При цьому поверхневі рішення, що охоплюють лише питання технологічної модернізації операційних процесів або автоматизації окремих елементів не дають очікуваної результативності і змушують власників бізнесу припиняти реалізацію проєктів цифрової трансформації. Досягнення ефективності можливе за умови комплексного підходу до перегляду існуючої бізнес-моделі та ціннісної пропозиції, процесів, продуктів та супутніх сервісів, клієнтського і партнерського обслуговування, 3 чітким формулюванням мети цифрових трансформацій, оцінкою готовності технологічної інфраструктури, персоналу, основних стейкхолдерів до сприйняття 
запланованих змін. У стратегічному вимірі компанії продовжують рухатись у напрямку впевненого розвитку та генерації прибутку, доповнюючи стратегічні положення необхідністю збереження продуктивності працівників і трансформації бізнес-процесів, продуктів та сервісів, частина з яких має бути вирішена у поточному режимі. Отже, необхідним $є$ здійснення більш ретельного аналізу успішних кейсів цифрових трансформацій бізнесу, визначення ключових аспектів їх реалізації за різними галузями економічних діяльності 3 метою формулювання механізмів забезпечення стійких конкурентних переваг в умовах загальносвітової нестабільності.

\section{СПИСОК ВИКОРИСТАНИХ ДЖЕРЕЛ}

1. Harry Bouwman, Shahrokh Nikou, Francisco J. Molina-Castillo, Mark de Reuver. The impact of digitalization on business models. Digital Policy, Regulation and Governance. 2018. Vol. 20. № 2. P. 105-124.

2. Гриценко О. А. Цифрова економіка: сучасні виклики для економістів та правознавців. Економічна теорія та право. 2018. № 2 (33). С. 77-90.

3. David L. Rogers. The digital transformation playbook. Columbia Business School Publishing. 2016. 293 p.

4. Vipin Jain. Emerging Digital Business Opportunities and Value. Data Analytics \& Digital Technologies, 2017. URL: https://www.cutter.com/article/emerging-digital-businessopportunities-and-value-496376 (дата звернення 12.10.2020)

5. Наторіна А.О. Фундамент цифрової трансформації бізнесу. Управління розвитком, 2018. № 1 (191). С. 55-60.

6. Лісова Р.М. Вплив діджиталізації на бізнес-моделі: етапи та інструменти цифрової трансформації. Науковий вісник Ужгородського національного університету. 2019. № 24. Ч.2. С. 114-118.

7. The role of technology in the socio-economic development of the post-quarantine world : monograph. Edited by Magdalena Gawron-Łapuszek, Andrii Karpenko. Publishing House of Katowice School of Technology, 2020. 467 p.

8. Краус Н.М., Голобородько О.П., Краус К.М. Цифрова економіка: тренди та перспективи авангардного характеру розвитку. Ефективна економіка, 2018. №1. URL: https://www.researchgate.net/publication/335858332_Cifrova_ekonomika_trendi_ta_perspekt ivi_avangardnogo_harakteru_rozvitku (дата звернення 19.09.2020)

9. Tammy Alairys, Jim Little, Mazen Baroudi, Rohit Joshi. The combinatorial effect of emerging technologies. Ernst \& Young, 2020. 12 p.

10. Ткачук Г.О. Цифрові трансформації: взаємозв'язок із системою економічної безпеки підприємства. Економіка харчової промисловості. 2019. Т. 11, Вип. 4. С. 42-50.

11. Tomoko Yokoi, Jialu Shan, Michael Wade, James Macaulay. Digital Vortex 2019: Continuous and connected change. The Global Center for Digital Business Transformation, 2019. 16 p.

12. Unlocking success in digital transformations. McKinsey survey. 2018. URL: https://www.mckinsey.com/business-functions/organization/our-insights/unlocking-successin-digital-transformations (дата звернення 21.11.2020)

13. Цифрова трансформація бізнесу: як це роблять компанії в Україні? URL: https://ua.interfax.com.ua/news/press-release/640817.html (дата звернення 18.11.2020)

14. Digital transformation of Ukraine: Vision 2025. Інфографічний довідник. ТОП ЛІД. 2019. $35 \mathrm{c}$.

15. International Telecommunications Union. ICT Infrastructure and Market Structure. URL: https://www.itu.int/net4/ITU-D/icteye\#/compare (дата звернення 15.10.2020) 


\section{REFERENCES}

1. Harry Bouwman, Shahrokh Nikou, Francisco J. Molina-Castillo, Mark de Reuver (2018). The impact of digitalization on business models. Digital Policy, Regulation and Governance, Vol. 20, № 2, 105-124. doi : 10.1108/DPRG-07-2017-0039

2. Grycenko O. A. (2018). Cyfrova ekonomika: suchasni vyklyky dlya ekonomistiv ta pravoznavciv. Ekonomichna teoriya ta pravo, № 2 (33), 77-90.

3. David L. Rogers (2016). The digital transformation playbook. Columbia Business School Publishing, 293 p.

4. Vipin Jain. Emerging Digital Business Opportunities and Value (2017). Data Analytics \& Digital Technologies. URL: https://www.cutter.com/article/emerging-digital-businessopportunities-and-value-496376 (Assessed on 12.10.2020)

5. Natorina A. O. (2018). Fundament cyfrovoyi transformaciyi biznesu. Upravlinnya rozvytkom, № 1 (191), 55-60.

6. Lisova R. M. (2019). Vplyv didzhytalizaciyi na biznes-modeli: etapy ta instrumenty cyfrovoyi transformaciyi. Naukovyj visnyk Uzhgorodskogo nacionalnogo universytetu, № 24 . Vol.2, 114-118.

7. The role of technology in the socio-economic development of the post-quarantine world : monograph. Edited by Magdalena Gawron-Łapuszek, Andrii Karpenko. Publishing House of Katowice School of Technology, 2020. 467 p.

8. Kraus N. M., Goloborodko O. P., Kraus K. M. (2018). Cyfrova ekonomika: trendy ta perspektyvy avangardnogo xarakteru rozvytku. Efektyvna ekonomika, №1. URL: https://www.researchgate.net/publication/335858332_Cifrova_ekonomika_trendi_ta_perspekt ivi_avangardnogo_harakteru_rozvitku (Assessed on 19.09.2020)

9. Tammy Alairys, Jim Little, Mazen Baroudi, Rohit Joshi (2020). The combinatorial effect of emerging technologies. Ernst \& Young, 12 p.

10. Tkachuk G.O. Cyfrovi transformaciyi: vzayemozvyazok iz systemoyu ekonomichnoyi bezpeky pidpryyemstva (2019). Ekonomika harchovoyi promyslovosti, T.11, Vol. 4, 42-50.

11. Tomoko Yokoi, Jialu Shan, Michael Wade, James Macaulay (2019). Digital Vortex 2019: Continuous and connected change. The Global Center for Digital Business Transformation, $16 \mathrm{p}$.

12. Unlocking success in digital transformations. McKinsey survey, 2018. URL: https://www.mckinsey.com/business-functions/organization/our-insights/unlocking-successin-digital-transformations (Assessed on 21.11.2020)

13. Cyfrova transformaciya biznesu: yak ce roblyat kompaniyi $\mathrm{v}$ Ukrayini? URL: https://ua.interfax.com.ua/news/press-release/640817.html (Assessed on 18.11.2020)

14. Digital transformation of Ukraine: Vision 2025. Infografichnyj dovidnyk. TOP LEAD, 2019. $35 \mathrm{p}$.

15. International Telecommunications Union. ICT Infrastructure and Market Structure. URL: https://www.itu.int/net4/ITU-D/icteye\#/compare (Assessed on 15.10.2020)

Бей А.В., к.э.н., доцент кафедры менеджмента и поведенческой экономики Донецкого национального университета имени Васыля Стуса, ORCID: 0000-0002-6367-3494

h.larycheva@donnu.edu.ua

СТРАТЕГИЧЕСКИЕ И ТАКТИЧЕСКИЕ ВОПРОСЫ УСПЕШНОЙ ТРАНСФОРМАЦИИ БИЗНЕСА В УСЛОВИЯХ НОВОЙ ЦИФРОВОЙ РЕАЛЬНОСТИ

В статье рассмотрены характерные особенности и ключевые вопросы осуществления успешной трансформачии бизнеса в условиях становления цифровой экономики и появления новых вызовов сочиально-экономического развития. Доказано, что развитие ичифровой экономики ускоряется в связи с влиянием всеобъемлющего распространения информационных, коммуникационных и прорывных технологий, возникновением на их основе комбинаторного эффекта, что позволяет получать 
множество новых технологических и управленческих решений. Определен характер обоснованных изменений, которые сопровождают экономическую деятельность субъектов ведения бизнеса в новых условиях, в частности изменения в рыночной модели экономического поведения, технологической инфраструктуре, бизнес-процессах и ключевые отрасли, которые испытывают наибольшее влияние от действия прорывных цчифровых технологий. Представлены типичные тенденичи осуществления цифровых преобразований в различных отраслях и проанализированы факторы, позволяющце достигать успешности в реализации проектов циифровых преобразований, степень развитости базовой цฺифровой инфраструктуры. Сформулированы основные положения реализации успешных изифровых трансформаций бизнеса с точки зрения стратегического видения и определены первоочередные тактические вопросы достижения желаемого уровня конкурентоспособности и удержания лидерских позиичй.

Ключевые слова: циифровая экономика, трансформация бизнеса, прорывные технологии, стратегия, информационные системы.

H. Bei, PhD, Associate Prof. of the Department of Management and Behavioral Economics, Vasyl' Stus Donetsk National University, ORCID: 0000-0002-6367-3494

h.larycheva@donnu.edu.ua

STRATEGIC AND TACTICAL ISSUES OF SUCCESSFUL BUSINESS TRANSFORMATION IN THE CONDITIONS OF NEW DIGITAL REALITY

The article considers characteristics and key issues of successful business transformation in the digital economy and the emergence of new challenges of socio-economic development. It is proved that the development of the digital economy is accelerating due to the influence of the widespread spread of information, communication and breakthrough technologies, the emergence of a combinatorial effect based on them, which allows to obtain many new technological and managerial solutions. The nature of justified changes accompanying economic activity of business entities in the new environment, changes in the market model of economic behavior, technological infrastructure, business processes and key industries that are most affected by the breakthrough digital technologies are defined. Typical trends in the implementation of digital transformations in various industries are presented and the factors that allow to achieve success in the implementation of digital transformation projects and development degree of the basic digital infrastructure are analyzed. The main provisions of the successful digital business transformations implementation from the point of view of strategic vision are formulated and the priority tactical issues of achieving the desired level of competitiveness and maintaining leadership positions are identified.

Keywords: digital economy, business transformation, breakthrough technologies, strategy, information systems. 